\title{
"And all Hell Broke Loose": How Child Maintenance Regulations Contribute to Re-actualizing Intimate Partner Violence between Separated Parents in Sweden
}

\author{
${\text { Helena } \text { Tegler }^{1} \text { (D) } \cdot \text { Stina Fernqvist }}^{1}$ (D) $\cdot$ Marie Flinkfeldt $^{1}$ (D)
}

Accepted: 18 January 2022 / Published online: 21 January 2022

(c) The Author(s) 2022

\begin{abstract}
This study examines recent changes in Swedish regulations for child maintenance in relation to post-separation families with experiences of either intimate partner violence (IPV) or conflict. The reform limited the possibility to rely on the state for maintenance in cases of cooperation difficulties. For IPV cases, the Swedish Social Insurance Agency (SSIA) can function as an intermediary between parents, but such exceptions are made upon assessment and require disclosure of IPV. This study investigates consequences of the maintenance reform and the ways in which it may re-actualize conflict and IPV between separated parents. Data consist of 649 recorded phone calls $(\sim 55 \mathrm{~h})$ to the SSIA concerning maintenance. Disclosures of post-separation conflict or IPV were found in 132 of these calls; these calls were analyzed using thematic analysis. The maintenance reform's requirement to reinstate contact with a former partner can re-actualize experiences of parental conflict as well as IPV by (a) re-surfacing physical or psychological abuse; (b) continued or accelerated cooperative difficulties; (c) renewed financial control; and (d) 'paper abuse' and new possibilities to display diligence or exert camouflaged control. This can take the form of explicit acts of abuse, anxiety or concern caused by the renewed contact, or being forced to deal with difficult memories. We argue that the Swedish maintenance reform ignores the reality of parental conflicts and IPV by re-actualizing such experiences in a range of ways.
\end{abstract}

Keywords Child maintenance $\cdot$ Family policy $\cdot$ Intimate partner violence $\cdot$ Social insurance $\cdot$ Separation $\cdot$ Maintenance support

\section{Introduction}

Family policies promoting gender equality and parents' shared responsibility for their children's well-being typically presume that parents are able to cooperate with each other, even after their relationship has ended. In Sweden, this is pivotal in regulations and court decisions on custody (SFS 1949:381, 6 chap. 5§), which are underpinned by parents' shared legal responsibility and the assumption that children benefit from contact with both parents (Bill 2014/15:145; Blomqvist \& Heimer, 2016). However, in cases where there are or have been occurrences of intimate partner violence (IPV), the assumption that parental cooperation is possible

Helena Tegler

helena.tegler@soc.uu.se

1 Center for Social Work (CESAR), Department of Sociology, Uppsala University, Box 624, 75126 Uppsala, Sweden and desirable can be problematic due to the increased risk of violence that may follow due to increased opportunities and areas for contact between separated parents (Bruno, 2018; Diesen, 2016; Eriksson, 2011; James-Hanman \& Holt, 2021).

A key area for contact between separated parents, in cases where custody is not shared equally, is child maintenance (or child support). Regulations and arrangements vary between countries, but typically involve a regular transfer of a specified sum from the liable (non-resident) parent to the resident parent, in order to cover a share of the costs for the child. Arrangements requiring parents to coordinate maintenance payments may impose risks related to IPV (Cook et al., 2015; Pearson et al., 2001). The Swedish regulations in this area have previously allowed parents to use the Swedish Social Insurance Agency (SSIA) - a government agency administrating various social insurance benefits - as an intermediary to avoid direct contact with the other parent about financial issues. In 2016, however, the maintenance 
regulations were reformed to increase contact between separated parents and the current default arrangement is that parents agree on a suitable sum and manage the transfer themselves (Fernqvist, 2020). The SSIA currently handle maintenance transfers only in special circumstances, including experiences of IPV, or when the liable parent refuses or is unable to pay directly to the resident parent. At the time of the reform, both legal experts and interest groups such as the National Organization for Women's Shelters and Young Women's Shelters in Sweden (ROKS) argued that the new regulations could pose a risk for separated parents with previous experiences of abuse (Fernqvist, 2020). To date, there is little empirical knowledge about the impact of the regulations change on families and what problems its implementation have caused.

The aim of this article is to provide an understanding of the interplay between experiences of IPV and conflict on the one hand, and state welfare regulations and routines regarding child maintenance on the other hand. Specifically, we investigate how the child maintenance reform in Sweden in 2016 has contributed to maintaining or re-actualizing parental conflict and IPV post-separation. Previous research has acknowledged that although IPV may persist or even intensify after separation, this is an overlooked area associated with risk for women and children (Humphreys \& Thiara 2003; Brownridge, 2006), particularly in relation to child contact arrangements of various kinds (James-Hanman \& Holt, 2021). Due to the emphasis on contact and cooperation between separated parents that is stipulated by the reform, it is likely to assume that this issue would have relevance in this context. By re-actualization, we refer to the risk of reoccurring events, but also to experiences of fear, worry or discomfort. Re-actualization is therefore a somewhat broader concept than re-victimization, which refers to how an individual may be subjected to violence post-separation and the psychological effects it may cause (Kuijpers et al., 2012).

By examining a large number of recorded phone calls to the SSIA, we investigate how parents describe their situation before, during and after the reform's implementation, focusing on descriptions of conflict and violence. We distinguish conflict from violence by defining the latter as marked by inequality and a notable power imbalance, while conflict rather refers to disagreements over specific topics. There is a risk that using the concept of conflict in an unreflected manner could reduce the visibility of IPV (see also Brännvall, 2016; Eriksson, 2011). The distinction between violence and conflict is however 'empirically significant' in this article since occurrence of IPV may allow for maintenance support eligibility, while features of conflict do not. Research on disclosures of IPV in naturalistic environments has suggested that vague descriptions relating to conflict, on which occurrence of violence may be inferred, are common when victims and perpetrators talk about their experiences (Greatbatch
\& Dingwall, 1999; Tennent \& Weatherall, 2019). Since we draw on naturalistic talk in this study, we therefore view it as necessary to use both concepts to describe how certain events are framed in the data and to distinguish between situations that may be perceived as more threatening and perilous.

\section{Post-separation Family Policies and Maintenance in Sweden}

About $25 \%$ of all children aged 0-19 in Sweden have parents who are separated or divorced (ISF, 2019, p. 67). Separated parents with equally shared custody are not obliged to pay child maintenance in any form, but if the child lives with one of the parents more than $50 \%$ of the time, the resident parent is entitled to maintenance. The liable parent can either pay directly to the resident parent, or pay to the SSIA, who then pays the resident parent in the form of "maintenance support". The maintenance support scheme facilitates and guarantees child maintenance, for instance if the liable parent is unable or unwilling to pay. Despite the emphasis on equally distributed parental responsibilities post-separation, $87 \%$ of the resident parents receiving maintenance support in Sweden over the past two decades have been women (ISF, 2019). The total number of children within the SSIA maintenance scheme was 193800 in 2017, but official numbers have decreased over time and were markedly reduced when the maintenance reform of 2016 came into effect (Fernqvist, 2020; ISF, 2019), which was one of the reform's central aims.

Maintenance transactions handled by the parents themselves often ensure higher compensation levels since it, unlike maintenance support via the SSIA, is based on the parents' incomes. It can therefore be seen as more beneficial for the child. In addition to reducing the SSIA's administrative workload, the reform was motivated by parents' shared maintenance and custody responsibility post-separation (Bill 2014/15:145 p. 145). Prior to the reform, any parent could opt for maintenance support via the SSIA, without stating any particular reason. Previous studies have found that financial conflict, regarding e.g., maintenance arrangements, is a common area of conflict among separated parents in Sweden (Bergman \& Rejmer, 2017) and it can be assumed that access to maintenance support would reduce such conflicts. It is therefore likely that this benefit also prior to the reform was mostly used by parents who experienced some level of conflict and therefore handled the maintenance transactions through a government agency rather than deal directly with each other.

However, with the 2016 reform this possibility was restricted. The regulations stipulate that if the liable parent has paid maintenance to the SSIA for six consecutive months (from January 2022, this has been changed to twelve 
months), the SSIA ceases to intervene and the parents must organize the transfer themselves. If the claimant can invoke "special reasons" - previous incidence of IPV being the most prominent one - the SSIA's continued mediation of money transfers may be justified. This is assessed in each case, which means that parents will need to disclose having been subjected to abuse, and describe this abuse in sufficient detail for the SSIA to make a decision (Fernqvist, 2020).

The understanding that the SSIA provides protection has been central in debates on the maintenance reform. The following quote from our data illustrates how this works. Here, a case officer at the SSIA explains the "exception rule" to a mother who expresses worry about how renewed contact through the changing maintenance arrangements may lead to abuse:

So if you don't get any maintenance directly from the other parent, which I suspect you don't, and the child lives with you, you'll get maintenance support from us. We'll pay you and he'll pay us. We are the protection. (SSIA case officer, call 132)

Procedures regarding maintenance support entail that case officers are in contact with both parents and that information regarding e.g., claims of abuse have to be documented in a way that is accessible to both parents, which case officers have perceived as problematic (Fernqvist 2020). In addition, the special reason exception is not permanent, as cases need to be re-evaluated regularly. The 2016 reform stipulated a review every six months (the "six months rule") (ISF, 2019) - whereby experiences of violence may need to be revisited - but this is currently undergoing change and from January 2022 this time span may vary between six months and four years (see Bill, 2020/21:203).

After the reform, IPV has thus been more palpable in the SSIA's work routines, mainly because of the agency's new task of assessing special reasons for approving maintenance support. The relative lack of discussion of IPV in the government's preparatory activities leading up to the reform suggests that legislators did not expect so many special reason claims and may have underestimated how they would affect the case officers' work. In general, case officers have little or no training or experience of dealing with family conflict or IPV, and an interview study has indicated that they experience their interaction with maintenance support claimants as more complex and difficult after the reform (Fernqvist, 2020).

\section{Defining and Contextualizing IPV: The Swedish Case}

Internationally, the Nordic countries stand out in terms of equality-promoting policies (Bergqvist et al., 2007; Borchorst \& Siim, 2008). Previous research has however highlighted that since Swedish family policies are grounded in an overarching discourse of gender equality, an unequal distribution of responsibilities, power imbalances or violence between parents may be obscured (Eriksson, 2011). This is sometimes referred to as "The Nordic paradox" (Korkmaz, 2021). Approximately 25\% of Swedish women have experienced abuse at some point in their lifetime (Brå, 2014:8). In 2020, 23200 cases of abuse were reported to the police by women and in $80 \%$ of these cases the abuser and the victim were acquaintances and estimations indicate that only one quarter of IPV cases are reported (Brå, 2009:12).

IPV is often defined as various forms of physical, psychological, emotional, verbal, sexual and/or financial abuse between partners where the majority of victims worldwide are women (Lambert \& Firestone, 2000, p. 56), although, about $12 \%$ of men report being abused by a woman (Hines $\&$ Douglas, 2009). The characteristics of men's and women's violence differ; while men's violence often includes all the above mentioned parts of IPV women's violence is foremost characterized by emotional and psychological abuse (Williams et al., 2008). Both female and male victims tend to experience feelings of shame. Yet, men also describe feelings of being ridiculed and demasculinized, feelings that might be understood in the light of public stereotypical attributes of masculinity (Brooks et al., 2020). Abuse and control may continue after the relationship has ended and can sometimes escalate following separation or divorce (Brännvall, 2016; Miller \& Smolter, 2011). Women who have escaped from abusive relationships are a vulnerable group: about one-third report continuous abuse or harassment one year after the separation (Humphreys \& Thiara, 2003).

IPV, both during the relationship and post-separation, may have long-term effects on both the abused party and on the children who in one way or another experience it. It has been argued that "experiencing" is a more appropriate term than "witnessing" for describing how children are affected. Defining IPV as something that can be heard, felt and recalled in memory gives a richer and, some would argue, more accurate description of the consequences it may have for children even when they are not themselves directly subjected to violence (Eriksson, 2011; Överlien \& Hydén, 2009). In addition to commitments to gender equality, Swedish policies often emphasize children's rights. For instance, Sweden incorporated the United Nations Convention on the Right of the Child (CRC) in Swedish law in 2020 (McCallSmith, 2019; SFS 2018:119) and children who experience violence are regarded as crime victims according to the Swedish Social Services Act and the Criminal Injuries Act (Socialstyrelsen, 2016). However, scholars have argued that Swedish family policy still does not pay sufficient attention to how children experience parental abuse post-separation (Blomqvist \& Heimer, 2016; Eriksson, 2011) and it remains 
to be seen if or how the incorporation of the CRC will affect this.

Although financial abuse is often associated with other forms of IPV, it can also be defined as a specific form of spousal abuse (Adams et al., 2008) and is exerted, e.g., through one party's control of jointly owned financial resources and/or through more direct violent acts such as depriving the other of money, basic resources. It has been argued that welfare schemes in general, including the handling of child maintenance, may even facilitate economic abuse whereby perpetrators sustain their financial advantage and undermine their ex-partners' financial autonomy through the scheme's design. Natalier (2018) notes, for example, that child maintenance processes and the withholding of support in Australia may be regarded as economic abuse facilitated by the welfare state. Several women in Natalier's study described the lack of support payments as exercise of power, and that this form of abuse "undermined their ability to purchase food, housing, heating, child care, transport, education for themselves and their children, travel to maintain connections with family, holidays, clothes, medical care, and extra-curricular activities for their children" (p. 131). Other research has also suggested that, although child maintenance schemes are designed to mitigate money transfers between separated parents and reduce the risk of poverty for resident parents, they can instead increase the risk for financial insecurity and abuse (Fernqvist, 2020; Skinner \& Davidson, 2009). A report published by the Swedish Social Insurance Inspectorate after the first year of the reform suggests that child maintenance is a potential hotbed for conflict between separated parents; $61 \%$ of parents who applied for maintenance support after trying to handle the transactions themselves claimed that they were unable to cooperate, and of these, $29 \%$ claimed that cooperation efforts spurred new conflicts (ISF, 2019). It is of course difficult to say to what extent these numbers indicate abuse, but the increasing level of conflict as a consequence of the reform might be of relevance in this context.

\section{Methods}

This study is a qualitative analysis of a large database of phone calls from parents to the SSIA customer service. The database comprises 2255 recorded calls regarding a range of family benefits (Flinkfeldt \& Näsman, 2019); in this study we have examined all calls relating to child maintenance, which amounted to 649 calls ( $~ 55 \mathrm{~h}$ of audio data). The calls were recorded in 2016 and 2017, i.e., at the time when the reform was launched and many parents received letters informing them of the reform and that the SSIA would no longer function as an intermediary party. The recorded customer service line is the default mode of contact for parents with questions or objections relating to the reform. At the time of recording, the customer service for maintenance support was staffed by trained case officers, of which many had university degrees but little or no training specifically relating to IPV. Nine SSIA call-takers working with maintenance support gave written, informed consent to participating and all their calls were subsequently recorded without any pre-selection criteria. Callers were given oral information about the study in a pre-recorded message while waiting to be connected to a case officer and were encouraged to tell the case officer if they wished to be excluded. No additional personal information (beyond what is mentioned in the calls) was collected and names, geographical references, etc. have been changed in all transcribed examples. The study has been approved by the Ethical Review Board in [Reference no. 2016/073].

Examining how clients describe their situation in naturally occurring contacts with public authorities enables direct insight into situated meaning-making processes, as they unfold in real-life situations. Naturally occurring interaction is an underused data source for researching how social problems are constructed and dealt with, and can give unique insights into the problems that are treated as especially difficult or important in a particular context (Potter, 2002). In this case, it allows us to see which problems parents bring up when talking with the SSIA, and how they describe those problems to the case officer. While research interviews can generate rich accounts of a pre-specified topic, investigating naturally occurring descriptions generates knowledge on what information that is deemed relevant and what experiences that surface as part of conducting institutional business (Iversen et al., 2021).

Data were analyzed stepwise. First, the total batch of 649 recorded phone calls was listened through and notes were made about call purpose, descriptions of violence or conflict, etc. One hundred thirty-two of the calls $(\sim 17 \mathrm{~h})$ featured talk about conflict and/or violence before, during or after separation, and these were selected for further analysis and transcribed in full. The average length of the calls in this analyzed subset was about $8 \mathrm{~min}$, which was about $50 \%$ longer than the calls about maintenance support that did not feature talk about conflict or violence. The callers comprised 87 women (75 resident mothers and 12 liable mothers) and 45 men (10 resident fathers and 35 liable fathers). Both liable and resident parents addressed conflict in relation to payments, but although there were exceptions, resident mothers in particular described events consistent with IPV, while liable fathers argued that they had to pay too high amounts or reported conflict regarding other aspects of the maintenance arrangements (e.g. not being able to see the child).

In order to detect the interplay between experiences of IPV and state welfare regulations and routines regarding child maintenance, it was important to also include calls where conflicts of various kinds were brought up. A reason 
for this is that disclosing IPV is associated with a range of difficulties, so that abused victims (if raising the topic at all) may normalize or minimize their experiences (Greatbatch \& Dingwall, 1999; Liang et al., 2005). Talking about IPV can invoke feelings of shame, self-blame or fear of being punished; IPV is sometimes considered a private family matter that should not be shared with outsiders; and victims may be discouraged by previous experiences of encountering disbelief or blame when disclosing IPV (Brooks et al., 2020; Kennedy et al., 2021; Tennent \& Weatherall, 2019). A more inclusive approach is therefore necessary when studying naturalistic situations. Investigating talk about the full range of parental conflict that is visible in our data allows us to identify what experiences of conflictual situations that parents describe - including IPV - and how these relate to the child maintenance reform.

After forming the subset of 132 calls, transcripts were read through repeatedly and coded in the software program NVivo, in accordance with thematic analytic (TA) methods. TA is a theoretically flexible, descriptive approach identifying, analyzing and reporting patterned meaning in qualitative data (Braun \& Clarke, 2006, 2021; Vaismoradi et al., 2013). The coding in the study was conducted in line with what Braun and Clarke (2021) call 'reflexive' thematic analysis - an unstructured approach focused on developing codes into themes that are underpinned by a central organizing concept. The analysis involved a step-wise gathering of increasingly abstract categories, eventually forming four broader themes that related to what we conceptualized as re-actualization of conflict and IPV. Identifying, defining and naming the themes was a collaborative, iterative process. The coding structure was repeatedly reviewed in the research team based on Braun and Clarke's (2006, p. 91) recommendation that "[d]ata within themes should cohere together meaningfully, while there should be clear and identifiable distinctions between themes".

\section{Results}

The analysis suggests that being required to reinstate contact with a former partner can re-actualize previous experiences of parental conflict as well as IPV. This can take the form of explicit acts of abuse, anxiety or concern about possible abuse caused by the renewed contact, or more indirectly being forced to deal with difficult memories as part of supporting a request for continued maintenance support via the SSIA (to avoid contact with the other parent). The analytic process generated four themes that show different ways in which the maintenance reform contributes to maintaining or re-actualizing conflict and IPV (a) re-surfacing physical or psychological abuse; (b) continued or accelerated cooperative difficulties; (c) renewed financial control; and (d) 'paper abuse' and new possibilities to display diligence or exert camouflaged control.

\section{Re-surfacing Physical or Psychological Abuse}

In our data, some mothers (but no fathers) described direct contact with their former partner as associated with potential danger, mentioning physical and psychological violence including harassment and threats. This corresponds with previous research on women's experiences of post-separation abuse (Brännvall, 2016; James-Hanman \& Holt, 2021). For this group, interaction regarding maintenance can therefore be risky (Natalier, 2018). Some of the mothers described being afraid and cried when objecting to being forced to have direct contact with their former partner on a regular basis. In a few cases, the letter from the SSIA had spurred violent acts, but for the most part it was talk about fear and worry that made us see this as re-actualizing previous experiences. In the following example, a mother had applied for maintenance support at the SSIA (thus requesting to use the agency as an intermediary), and this had induced abusive behavior from the father. The example illustrates how maintenance-related issues can lead to increased contact and abuse, even when an intermediary agency steps in:

(1) On Friday my ex received a paper [from the SSIA] about maintenance. ((Sighs)) And all hell broke loose. He was here and banged on the door and yelled and sent texts to our thirteen-year-old about what a fucking awful person I am who has applied for maintenance. (Mother, call 2179)

Many calls were from parents who contacted the SSIA after having received a letter with information about the new regulations demanding them to interact directly with the other parent and to solve the financial transfer without SSIA's mediation. Leaving a violent relationship is often a challenging process and victims seldom report abuse before they feel emotionally safe and cognitively separated from their former perpetrators (Kennedy et al., 2021; Rober et al., 2006; Tennent \& Weatherall, 2019, pp. 270-288). In line with this, perhaps, only a few of the mothers who described IPV provided detailed information about the former partner's violent behavior. By phrasing the forced contact as "unwise" or something that "does not work", they appealed to the SSIA officers' own judgment without demanding special treatment or making IPV experiences explicit. The following example shows a way in which this was done, and how it was only after the SSIA officer indicated that the request for continued maintenance support could not be granted that a history of IPV was brought up:

(2) It says there [in the letter from the SSIA] that my daughter's dad and I will deal with [the maintenance] 
ourselves and that it won't be through you anymore, but I don't agree with that. (...) He and I should have as little contact as possible, that's best. (...) (SSIA officer: There must be special reasons if it is to continue to go through us.) Okay but then I have special reasons, because he's threatened me before so I have reported him to the police. (Mother, call 1886)

In a few instances, the mothers described the events in more detail, including references to persons, places and explicit violent actions. In the next example, however, the mother chose to disclose detailed information to the case officer after eleven minutes of talk, in order to support her claim. She described potentially life-threatening events as a background to her worry what would happen if they were to have contact with each other:

(3) He has been charged with damage and physical abuse, which means that I can't be in the residence as usual (...) If I' $m$ there at the same time I don't know what will happen next time. We ended a long relationship with him throwing, we had a boat, he threw all my belongings worth over a hundred thousand into the water, and me. I swam in my clothes for an hour from the boat. Then I never came back when he was present of course. (Mother, call 2340)

In some cases, the mothers objected to the requirement regarding contact by referring to previous physical abuse in front of the children. They also supported these accounts by mentioning social service interventions intended to protect the children from the other parent. Even though the physical and psychological abuse happened in the past, the mothers did not trust their former partner and resisted further contact:

(4) Yeah, I've been exposed to physical abuse from my ex. Social services have been involved and such things. I don't trust him completely either. Because this physical abuse has taken place... in front of the children too. (Mother, call 2305)

Having to deal directly with their former partner caused anxiety and concern. Mothers expressed fear, not only for their own safety but for their children's, as in the example above. Some mothers talked about the need to protect their children from the father and calculated the potential risk of violence in relation to their own actions, sometimes suggesting that they would abstain from maintenance in order to avoid problems. Direct contact with the former partner was thereby framed as a risk in relation to intensified threats and abuse targeting not only themselves but also their children. According to one of the mothers "the most important thing is to spare the children from fighting and things" (Mother, call 1988, example 5).
The reform also seems to have spurred stalking behavior in some cases. The mothers in our data described recurrent threatening phone calls and text messages from their former partner. Some said that they did not report it to the police because they were unsure how it would affect the child. Sometimes the mothers pinned their hopes on support from the social services or the school welfare officer:

(6) I've received threats and nightly calls, but it [a police report] doesn't benefit our daughter right now. It's the second time he writes about me to our daughter and the counsellor at the school will probably deal with this in time but she [the daughter] is harmed by this you know and it's only getting worse. (Mother, call 2179)

In conclusion, our data indicate that the reform in these cases has contributed to maintaining or re-actualizing fear of physical and/or psychological abuse or harassment. Although the financial transfer did not necessarily involve direct physical contact, there were cases where the liable parent intruded and threatened the resident parent as well as the child, or where the caller described anticipation and worry about such behaviors.

\section{Continued or Accelerated Cooperative Difficulties}

Another recurring theme in the calls -less clearly connected to IPV but nevertheless relevant for understanding the consequences of the maintenance reform - was cooperative difficulties that hindered parents to agree on a maintenance amount or to manage financial transfers. The parents' accounts were either focused on dislike or aversion linked to fear or anxiety, and they described the imposed contact as"tense", "infected", "strained", or even"catastrophic", saying that contact was "not possible", "did not work" or pointing out that they "did not talk". In light of example 2 , it is possible that some of the situations described actually involve some form of IPV, although this is not spelled out. Parents who were not on speaking terms found it very difficult to cooperate regarding maintenance and displayed resistance to the new regulations that forced them to have monthly financial contact with the other parent. For instance, one mother communicated that "me and their father don't have any contact you know. I haven't talked to him since April last year, the situation is tense" (Mother, call 1988, example 7) and another mother stated that "we barely talk to each other you know. Now this is disaster" (Mother, call 1895, example 8).

Some parents sought to avoid contact with their former partner even though years had passed since the separation. They searched for ways to circumvent the conflicted situation, and in some cases also the risk of being exposed to verbal abuse or harassment. The situation with the former 
partner was described as contaminated with previous negative experiences, making direct contact impossible. Even though the majority of IPV research has focused on men's violence against women, there is a small body of research that has addressed and analyzed women's violence against men, for instance showing that it is often psychological or verbal rather that physical (Williams et al., 2008). This can be seen in the following example, where a father resisted contact with his ex-partner, anticipating verbal abuse although they had been separated for nine years:

(9) Because I don't want to answer her, that's the way it is. It's so infected. Has been even though it's nine years ago, there has been a trial and there has been a settlement and like other things that I don't want to. Yeah so. Like I don't want all that taunting. (Father, call 2259)

In some cases, the parents were emotional, crying or sobbing, as they argued that they should not have to deal with the liable parent, sometimes also invoking worry or fear. In our data, only mothers displayed emotion in this way, but this of course does not mean that fathers did not experience similar emotions. This discrepancy might be explained by gendered norms about emotional expression (Addis \& Mahalik, 2003) or that they in fact had not been exposed to violence. The following example features a mother who has called the SSIA after having received a letter about the change in regulations:

(10) It says that, oh sorry ((cries)), it says that I have to make an agreement with the other parent although I have sole custody of the children and it's not possible! (...) ((cries)) I don't know what to do? I've had sole custody for over a year and we haven't spoken to each other and the children haven't seen him in that time and he has the entire time said that he doesn't want to pay because he thinks that I sit here and get lots of money like (...) And I can't talk to him. It's not possible to give even an inch of access to the family here. (Mother, call 1834).

While IPV is not explicitly mentioned here, several features - beyond crying - suggest that the situation was distressing and problematic for the family. For instance, the expression that it is not possible to "give even an inch" suggests that the mother anticipated that renewed contact regarding maintenance would lead to worse things (with the unspoken continuation "or he will take a mile"). In addition, the mother not only described lack of contact but also mentioned that the father had previously bluntly refused to give her any money. This could indicate a history of financial abuse, although the case officer in this case did not treat it that way.

\section{Renewed Financial Control}

A recurrent theme, particularly in the calls from mothers, was that their former partner did not pay at all, payed only partially or irregularly, or made deductions that they were not entitled to. Withholding (parts of) the maintenance limits the resident parent's possibilities to support the child, but also causes an overall less stable financial situation that can affect them in various ways - it can thus be a strategy to exert financial control over the other (Cook et al., 2015; Natalier, 2018). It should be noted here that in Sweden, as in many other countries, men earn more money on a structural level than women (SCB, 2021), which makes the matter substantially gendered. The regulatory change stipulating payment without the SSIA as an intermediary thus provides an opportunity for the liable parent to gain or maintain control, and possibly financial abuse, over the resident parent.

Parents in our data described not knowing if, how much, or when the liable parent would make the financial transfer, and highlighted this as stressful and problematic. Experiences or anticipation of this were described in terms of worry or fear relating to financial insecurity:

(11) I'm very afraid that he won't be able to... or that he pays the money that I should get. (...) I've tried to talk to him about maintenance and that we should be able to sort this out, but he doesn't know what he makes a month. He doesn't know if he can pay anything. We don't agree and it's really not possible.

(Mother, call 2261)

Contrasting with example 10 in the previous section, example 11 does not necessarily link irregular or withheld payment to conscious or premeditated financial abuse (although the statement "we don't agree" might imply that the issue in fact goes beyond being unable to pay). It is important to note that some of the cases in our data likely had to do with the liable parent's negligence or inability to pay, rather than purposely withholding money as a form of abuse. The problems that resident parents described nevertheless point to some of the effects that the liable parent's payment strategies can have on their lives, which illustrate the risk imposed by the reform's implementation.

A clear pattern in our data was that the reform was seen as imposing additional financial strain, since the parents could not rely on their ex-partners' payments. Some parents saw the SSIA's intermediary role as a kind of insurance to avoid financial irregularities. Without this control system they suspected, or had experienced in the past, not receiving the monthly payment. In the next example, a father suggested that he had expected the mother to withhold his maintenance once the SSIA withdrew their engagement, and that she did this despite knowing the rules, once the SSIA no longer took a role of surveillance:'I haven't received anything you 
know. And I knew that it might be this way because perhaps she's known about this too I guess? (...) Then there's like no direct surveillance" (Father, call 1991, example 12).

In some instances, the resident parent had adapted to a situation where they would not receive payment from the liable parent. A recurrent theme was that the parents in our data seemed to adjust their understanding of the situation to their former partner's understanding, presenting their financial reality as an acceptable, albeit aggravating, circumstance. This is in line with research saying that IPV victims tend to normalize their experiences and gradually see themselves from the perpetrator's perspective and adapt to their motives (Lundgren, 2012). By taking their former partner's perspective regarding maintenance, resident parents might risk financial instability. Some mothers (but no fathers) in our data considered being "nice" and give their former partner repeated chances even though they suffered financially from doing so:

(13) We don't have great communication. [Him not paying] puts me in a jam you know. Should I be nice and give him a chance and wait or what do I do? Because I'm sitting here without that money so to speak. (Mother, call 2211)

In a similar vein, a mother described losing out on maintenance after the separation, out of consideration for the father who claimed he would commit suicide otherwise. She explicated that "I didn't apply right away... I didn't know if he was serious, but he said, he screamed it once after we'd separated that if he'd be forced to pay maintenance he would fucking kill himself" (Mother, call 1988, example 14). A threat to hurt oneself can be a form of psychological abuse and it can also be used for the purpose of control and manipulation (Humphreys \& Thiara, 2003). In the example above, the mother adjusted to the father's wishes by choosing to not pursue any maintenance, neither from the SSIA nor directly from the father. The father's threat thus had a direct effect on the mother's financial situation.

Another issue that relates to financial control concerns the practical details of administering direct payments between the parents. Some parents described discomfort related to managing the financial transfer, and even giving out their bank account or the number to the mobile payment system was described as generating anxiety. Case officers have also noted that the conversion of maintenance, from a benefit distributed by the SSIA to direct payment between parents, has opened up new possibilities for harassment by the perpetrator by e.g., paying irregularly or adding offensive and threatening remarks on the bank transaction. Aspects such as these suggest that procedures attached to the reform has facilitated a form of post separation abuse (Fernqvist, 2020; Natalier, 2018). The following example features the same mother as in example 14, who appealed to the SSIA officer, saying that she "begged" for them to continue administering her maintenance. In example 15 the mother subsided her request "it just makes my stomach lurch when I think about like leaving my bank details to him. (...) In the best of worlds I can get a letter from you where it continues as it has before" (Mother, call 1988, example 15).

In sum, our data shed light on the range of ways in which the reform can contribute, directly or indirectly, to financial insecurity and increased risk for financial abuse. Being forced to interact with the other parent can cause anxiety both regarding the financial situation and the contact in itself. It provides the liable parent with an opportunity to impose (or threat to impose) financial instability on the resident parent, or to pressure them to accept a smaller or more irregular sum. These problems can be difficult for the SSIA to spot, as they are used to dealing with parents' inability to pay based on his/her financial situation, which is treated as distinct from IPV.

\section{"Paper Abuse" and New Possibilities to Display Diligence or Exert Camouflaged Control}

The final theme illustrates how dealings with the SSIA (and likely other public authorities) can provide an opportunity for the liable parent to display diligence. This can be important since a parent's ability and interest in cooperating with the other parent post separation is highly valued in Swedish legislation and practice regarding custody and rights of access. It has been reported that mothers who, as a protective measure in relation to a violent father, restricts access to the child can be fined or even lose custody since her actions are perceived as unwillingness to comply with the norms of cooperation (Diesen, 2016). Reversely, demonstrating compliance with these norms can favor the parent in custody disputes. It is therefore reasonable to assume that nonresident parents (mostly fathers) may benefit from presenting themselves as willing to adapt to increased levels of contact to ensure proper payments of maintenance, as ordained by the reform.

In our data, parents who described conflict but nevertheless wanted to manage maintenance without interference of the SSIA overall presented themselves as the responsible, trustworthy and lawful person in the conflict, arguing that they, but not the other parent, were willing to follow the new regulations. Presenting oneself in this way might work in favor of a decision by the SSIA that the parents should indeed be able to manage maintenance without SSIA interference. We identified instances in our data where this diligent self-presentation might work to camouflage controlling behavior. In the example below, the father first stated that he, but not the mother, wanted to cooperate as he did not want to place any administrative 'burden' on the SSIA: 
(16) What I just want to know here really, it's a couple of things. She wants to go through the Social Insurance Agency. I don't want to burden the Social Insurance Agency really. I want to have the possibility to make, of course, this [a deduction] when he's with me (...) So she says "no but I want to do it all at the Social Insurance Agency". I mean, what gives her the right to decide? (...) The boy is a bit worried, a bit of a mommy's boy right now. So there were a lot of things that happened and it was messy. I finally was forced to threaten her [the mother], for the boy's sake. (Father, call 2294)

It can be noted that the father, in this example, mentioned that his position was motivated partly by being able to make deductions for time when he took care of their son (which is only possible if the financial transfer is not managed by SSIA). He also openly questioned the mother's right to decide and described himself as being forced to threaten the mother. This aligns with how perpetrators tend to externalize the reason for their actions; it is not their fault but someone else's, typically their (ex-) partner's (Lundgren, 2012, p. 57). The mother's resistance to having direct contact with the father in this case could - as the father suggests - very well be a strategy to prevent the father from making deductions that he is entitled to make. In light of the mentioned threats, however, it is possible that the mother tries to avoid direct contact with a previous perpetrator, in which case the father's claims could be part of, or work to facilitate, further abuse.

Instances such as this provide the SSIA case officers with a delicate problem. They are on the one hand presented with the story of a trustworthy citizen who claims being willing to pay maintenance, whereas they are on the other hand presented with a story that suggests that abusive or controlling behavior might be an issue. Previous research has shown that the reform has made case officers more aware of what impact economic abuse might have on (primarily) resident parents. One challenging aspect is the fact that case officers are prohibited by law to refuse a liable parent to pay directly to a resident parent, even in cases where the case officer has reason to suspect that there is an impending risk of abuse (Fernqvist, 2020). Unless special reasons have been invoked by one of the parents (usually the resident parent), the process will continue towards direct payments.

A related problem has to do with the opportunity to manipulate public authorities in order to cause problems for the resident parent, which has been conceptualized as 'paper abuse' (Miller \& Smolter, 2011). In one call, a mother had worked up a large debt to the SSIA since her ex-partner had applied for maintenance support without her knowledge, and had then for a considerable time hidden the letters and bills the SSIA sent to the mother. The father thus used the
SSIA to put the mother in a financially difficult situation. The following example illustrates another way in which the resident parent's maintenance arrangements with the SSIA can be hijacked by the liable parent in cases of IPV. Here, a mother has called to explain that during a previous call with the SSIA officer, her former partner sat next to her, forcing her to lie and make false statements in his favor:

(17) Because when Margareta [an SSIA officer] called he was sitting right beside me and then I had to say that. I was forced to say yes because he was sitting right next to me and for him this maintenance was a disaster, to think he would even pay at all. (Mother, call 1879)

The mother here claims that her previously supplied information, i.e., that her former partner had moved back in with her and their child, was false. The use of administrative procedures, on false premises, made the agency cancel the maintenance support, leaving the mother in a difficult financial situation. In the analyzed call the mother was questioned and asked to provide evidence to assure the SSIA officer of the legitimacy of her renewed maintenance support claim.

In sum, the analyses in this section have brought attention to the ways in which the SSIA can be manipulated as part of an abusive process. The new maintenance regulations have provided liable parents with an opportunity to exert abuse; if payments are made in an orderly fashion and the liable parent claims to be willing to make them directly to the resident parent, this opens up a window for further contact, which in turn may re-actualize IPV for the resident parent.

\section{Discussion}

By thematically analyzing how separated parents who called the SSIA about maintenance described experiences of conflict and IPV when dealing with the other parent, our analysis has highlighted a range of negative consequences of recent changes in maintenance support regulations in Sweden. Although the analytic approach does not allow us to generalize regarding the extent of the problems identified, it is clear from our results that increasing demands for parental contact post-separation may lead to new conflicts and resident parents and children may be put at risk of controlling behavior, threats, harassment, and violence from the liable parent. These observations have clear parallels in international research (see Cook et al., 2015; Natalier, 2018) and illustrate how the handling of child maintenance may become an arena for exerting intimate abuse post-separation in the Swedish welfare state. The normative and legal pressure to actively maintain contact and cooperate with the other parent post-separation - that underpinned the maintenance reform in 2016 - has been criticized by women's 
advocate groups as well as IPV researchers, who have argued that such demands may increase risk and suffering for IPV victims. Where IPV is a concern, the maintenance regulations still allow for the SSIA to function as an intermediary so that parents can avoid contact with each other. However, our analysis suggests that these matters are not as clear-cut as the legislation presumes, and the regulations themselves may re-actualize conflict and IPV in a range of ways.

For all identified themes in our data, worry or fear was raised in relation to renewed violence or conflict. It is thus not only explicit acts of violence that re-actualize these experiences, but the very possibility of forced contact can induce re-traumatization and generate anxiety about the future. In cases of IPV this re-actualization can incorporate (a) difficult memories, re-traumatization, and re-victimization; (b) renewed threats and various forms of violence; (c) concern, worry or anticipation of threats or violence. All these aspects may contribute to creating an "atmosphere of fear" (JamesHanman \& Holt, 2021: 1). The study thus confirms previous findings on post-separation abuse (e.g. James-Hanman \& Holt, 2021; Humphreys \& Thiara 2003; Brownridge, 2006) but also highlights how such issues may be linked to the organization of welfare schemes such as maintenance support. It is important to emphasize that re-actualization, as we have discussed it here, can occur regardless of whether the SSIA subsequently assesses the case as an instance of IPV and steps in as an intermediary, as our analysis has pointed at how initiating the bureaucratic process is itself a sensitive matter and that parents with experiences of IPV or conflict react strongly to the communication letters from the SSIA. The possibility for the SSIA to make an exception to the default rule that parents should manage maintenance themselves is thus insufficient for avoiding the problems laid out in this article, since such an exception is made upon request and follows an investigation process which in itself may re-actualize violence or conflict. Although work routines may have changed since the data were collected during the implementation of the reform, the legislation relating to 'special reasons' eligibility for maintenance support is largely unmodified, suggesting that the problem remains.

Although our data do not allow for analysis of what happens further on in these cases our results highlight what has previously been called 'the six months rule' as particularly problematic. This is because this rule states that each case will be reviewed at specific time intervals (this time frame has been six months, but after heavy criticism, this was changed and will from 2022 onwards range from six months up to four years, see Bill, 2020/21:203), meaning that parents with experience of IPV need to subject to renewed assessment on a regular basis. This, in turn, means that experiences may need to be revisited and that it is impossible to ensure escaping forced direct contact with the other parent. It is thus not unlikely that some resident parents will avoid applying for maintenance support from the SSIA despite not receiving any maintenance from the other parent. It is beyond the scope for this study to investigate this further, but the risk has been addressed in the public evaluation of the reform (ISF, 2019). The maintenance reform might therefore restrict the possibilities for parents with a history of IPV (but also serious conflicts) to get the child maintenance to which they are eligible, which in the end may affect the welfare of both parents and children. Jeopardizing children's rights to maintenance is problematic in several respects, not least in relation to the recent incorporation of the CRC in Swedish legislation. Given the problems of the maintenance reform related to both IPV and conflict, it can therefore be questioned whether the benefits of the reform outweigh the negative consequences for these groups.

A final point of discussion is that the reform has made it necessary for SSIA case officers to distinguish between IPV and conflict in order to assess eligibility for maintenance support on the basis of IPV. The analyzed service calls constitute the first point of contact with the SSIA and therefore have an important gatekeeping function. To qualify for maintenance support, parents need to describe their experiences to the SSIA officer. Meanwhile, previous research has suggested that disclosing IPV in an institutional setting is not straight-forwardly done and that vague descriptions making violence inferentially available (e.g., describing conflict in more general terms) are recurrently used by both victims and perpetrators (Greatbatch \& Dingwall, 1999; Tennent \& Weatherall, 2019). While we see it as important to not confuse conflict and IPV, we thus also acknowledge that some of the descriptions of conflict in the analyzed calls may reflect situations of IPV without this being made explicit (and vice versa). It is a limitation of the study's naturally occurring data that it is not possible to ask further questions to verify or delve into the experiences described. Meanwhile, this very fact contributes insight into the difficulty of the case officers' task of assessing the validity of the callers' claims based on such vague descriptions. In the legislative works that laid the foundation for the maintenance reform, IPV was treated as straight-forwardly detectable, but our findings suggest this to be an over-simplification of how IPV is experienced and communicated. How IPV and conflict are distinguished from each other in naturalistic interactions is therefore an important question for further research, as well as policy and capacity building in welfare institutions.

Funding Open access funding provided by Uppsala University. This research was supported by grants from Swedish Social Services Agency (SSIA) awarded to Stina Fernqvist. 
Open Access This article is licensed under a Creative Commons Attribution 4.0 International License, which permits use, sharing, adaptation, distribution and reproduction in any medium or format, as long as you give appropriate credit to the original author(s) and the source, provide a link to the Creative Commons licence, and indicate if changes were made. The images or other third party material in this article are included in the article's Creative Commons licence, unless indicated otherwise in a credit line to the material. If material is not included in the article's Creative Commons licence and your intended use is not permitted by statutory regulation or exceeds the permitted use, you will need to obtain permission directly from the copyright holder. To view a copy of this licence, visit http://creativecommons.org/licenses/by/4.0/.

\section{References}

Adams, A. E., Sullivan, C. M., Bybee, D., \& Greeson, M. R. (2008). Development of the scale of economic abuse. Violence against Women, 14(5), 563-588. https://doi.org/10.1177/1077801208 315529

Addis, M. E., \& Mahalik, J. R. (2003). Men, masculinity, and the contexts of help seeking. The American Psychologist, 58(1), 5-14. https://doi.org/10.1037/0003-066X.58.1.5

Bergman, A.-S., \& Rejmer, A. (2017). Parents in child custody disputes: Why are they disputing? Journal of Child Custody, 14(2-3), 134-150. https://doi.org/10.1080/15379418.2017.1365320

Bergqvist, C., Blandy Olsson, T., \& Sainsbury, D. (2007). Swedish state feminism: continuity and change. In J. Outshoorn \& J. Kantola (Eds.), Changing state feminism. Basingstoke: Palgrave Macmillan.

Bill 2014/15:145. Ökad reglering av barns underhåll utanför underhållsstödet.

Bill 2020/21:203. Justerad indragningsbestämmelse inom underhållsstödet.

Blomqvist, P., \& Heimer, M. (2016). Equal parenting when families break apart: Alternating residence and the best interests of the child in Sweden. Social Policy \& Administration, 50(4), 787-804.

Borchorst, A., \& Siim, B. (2008). Woman-friendly policies and state feminism: Theorizing Scandinavian gender equality. Feminist Theory, 9(2), 207-224. https://doi.org/10.1177/1464700108090411

Brå/Brottsförebyggande rådet (2009:12) Våld mot kvinnor och män $i$ nära relationer [Crime in intimate relationships. A national survey]. Retrieved from https://bra.se/publikationer/arkiv/publikatio ner/2009-05-28-vald-mot-kvinnor-och-man-i-nara-relationer.html. Accessed 06 Dec 2021.

Brå/Brottsförebyggande rådet. (2014:8). Brott i nära relation. En nationell kartläggning [Crime in intimate relationships. A national survey]. Ordförrådet $\mathrm{AB}$. Retrieved from https://www. bra.se/publikationer/arkiv/publikationer/2014-05-09-brott-i-nararelationer.html. Accessed 06 Dec 2021.

Brännvall, M. (2016). Frigörelse med förhinder. Om polisanmälan när kvinnor tar sig ur mäns våld $i$ nära relationer [Liberation with impediment. Police rapport about women escaping men's violence]. [Doctoral Dissertation, Malmö University].

Braun, V., \& Clarke, V. (2006). Using thematic analysis in psychology. Qualitative Research in Psychology, 3(2), 77-101. https://doi.org/ 10.1191/1478088706qp063oa

Braun, V., \& Clarke, V. (2021). To saturate or not to saturate? Questioning data saturation as a useful concept for thematic analysis and sample-size rationales. Qualitative Research in Sport, Exercise and Health, 13(2), 201-216. https://doi.org/10.1080/21596 76X.2019.1704846

Brooks, C., Martin, S., Broda, L., \& Poudrier, J. (2020). "How many silences are there?" Men's experience of victimization in intimate partner relationships. Journal of Interpersonal Violence,
35(23-24), 5390-5413. https://doi.org/10.1177/0886260517 719905

Brownridge, D. (2006). Violence against women post-separation. Aggression and Violent Behavior, 11(5), 514-530. https://doi. org/10.1016/j.avb.2006.01.009

Bruno, L. (2018). Financial oppression and post-separation child positions in Sweden. European Journal of Social Work, 21(2), 181-192. https://doi.org/10.1080/13691457.2017.1286296

Cook, K., McKenzie, H., Natalier, K., \& Young, L. (2015). Institutional processes and the production of gender inequalities: The case of Australian child support research and administration. Critical Social Policy, 35(4), 512-534. https://doi.org/10.1177/ 0261018315599731

Diesen, E. (2016). Våld och vårdnad [Violence and cusody]. In. Stockholm: Roks, Riksorganisationen för kvinnojourer och tjejjourer i Sverige. Retreived from https://www.roks.se/sites/default/files/ 2017-03/Va\%CC\% 8Ald\%20och\%20va\%CC\% 8Ardnad\%20slu tlig\%20version.pdf. Accessed 02 Dec 2021.

Eriksson, M. (2011). Contact, shared parenting, and violence: Children as witnesses of domestic violence in Sweden. International Journal of Law, Policy, and the Family, 25(2), 165-183. https:// doi.org/10.1093/lawfam/ebr004

Fernqvist, S. (2020). Samarbete med förhinder. Perspektiv från boföräldrar och handläggare på underhållsstödsreformen 2016 [Cooperation with impediment. Resident parents' and administrators perspective of the Mainenance reform 2016]. (Socialförsäkringsrapport 2020:4). Försäkringskassan, Analys och prognos

Flinkfeldt, M., \& Näsman, E. (2019). På tal om pengar. Problembeskrivningar, hjälp och bemötande när barnfamiljer ringer till Försäkringskassan [Speaking of money: Problem formulation, response and conduct when financially vulnerable families call the Social Insurance Agency]. (Social insurance report 2019:4), Försäkringskassan, Analys och prognos [Swedish Social Service Agency, Analysis and prognosis], Stockholm.

Greatbatch, D., \& Dingwall, R. (1999). The marginalization of domestic violence in divorce mediation. International Journal of Law, Policy, and the Family, 13(2), 174-190. https://doi.org/10.1093/ lawfam/13.2.174

Hines, D. A., \& Douglas, E. M. (2009). Women's use of intimate partner violence against men: Prevalence, implications, and consequences. Journal of Aggression, Maltreatment \& Trauma, 18(6), 572-586. https://doi.org/10.1080/10926770903103099

Humphreys, C., \& Thiara, R. K. (2003). Neither justice nor protection: Women's experiences of post-separation violence. The Journal of Social Welfare \& Family Law, 25(3), 195-214. https://doi.org/10. 1080/0964906032000145948

ISF/Inspektionen för socialförsäkring. (2019). Från underhållsstöd till underhållsbidrag? En granskning av 2016 års reform inom underhållsstödet [From maintenance support to allowance? A review of the maintenance support regulations in 2016]. www.inspsf.se. Accessed 06 Dec 2021.

Iversen, C., Redmalm, D., Flinkfeldt, M., \& Persson, M. (2021). En människa bland andra? Äldre människors begripliggörande av vardagen under covid-19-krisen [A person among others? Older peoples' understandings of their everyday life during the Covid19 crisis]. Sociologisk forskning, 58(1-2), 53-76. https://doi.org/ $10.37062 /$ sf. 58.22100

James-Hanman, D., \& Holt, S. (2021). Post-separation contact and domestic violence: Our 7-point plan for safe[r] contact for children. Journal of Family Violence, 36(8), 991-1001. https://doi. org/10.1007/s10896-021-00256-7

Kennedy, A. C., Meier, E., \& Prock, K. A. (2021). A qualitative study of young women's abusive first relationships: What factors shape their process of disclosure? Journal of Family Violence. https:// doi.org/10.1007/s10896-021-00258-5 
Korkmaz, S. (2021). Youth Intimate Partner Violence in Sweden. Prevalence and Young People's Experiences of Violence and Abuse in Romantic Relationships [Doctoral Dissertation, Stockholm University].

Kuijpers, K. F., van der Knaap, L. M., \& Winkel, F. W. (2012). Risk of revictimization of intimate partner violence: The role of attachment, anger and violent behavior of the victim. Journal of Family Violence, 27(1), 33-44. https://doi.org/10.1007/ s10896-011-9399-8

Lambert, L. C., \& Firestone, J. M. (2000). Economic context and multiple abuse techniques. Violence against Women, 6(1), 49-67. https://doi.org/10.1177/1077801200006001004

Liang, B., Goodman, L., Tummala-Narra, P., \& Weintraub, S. (2005). A theoretical framework for understanding help-seeking processes among survivors of intimate partner violence. American Journal of Community Psychology, 36(1), 71-84. https://doi.org/10.1007/ s10464-005-6233-6

Lundgren, E. (2012). Våldets normalisering och andra våldsförståelser [The normalization of violence and other understandings of violence]. Stockholm: Riksorganisationen för kvinnojourer och tjejjourer i Sverige (ROKS).

McCall-Smith, K. (2019). To incorporate the CRC or not - is this really the question? The International Journal of Human Rights, 23(3), 425-441. https://doi.org/10.1080/13642987.2018.1558990

Miller, S. L., \& Smolter, N. L. (2011). "Paper Abuse": When all else fails, batterers use procedural stalking. Violence against Women, 17(5), 637-650. https://doi.org/10.1177/1077801211407290

Natalier, K. (2018). State facilitated economic abuse: A structural analysis of men deliberately withholding child support. Feminist Legal Studies, 26, 121-140.

Överlien, C., \& Hydén, M. (2009). Children's actions when experiencing domestic violence. Childhood, 16(4), 479-496. https://doi.org/ 10.1177/0907568209343757

Pearson, J., Griswold, E. A., \& Thoennes, N. (2001). Balancing safety and self-sufficiency: Lessons on serving victims of domestic violence for child support and public assistance agencies. Violence against Women, 7(2), 176-192. https://doi.org/10.1177/10778 010122182389

Potter, J. (2002). Two kinds of natural. Discourse Studies, 4(4), 539542. https://doi.org/10.1177/14614456020040040901
Rober, P., Eesbeek, D., \& Elliot, R. (2006). Talking about violence: A microanalysis of narrative processes in a family therapy session. Journal of Marital and Family Therapy, 32(3), 313-328. https:// doi.org/10.1111/j.1752-0606.2006.tb01609.x

SCB/Statistiska Centralbyrån (2021). Inkomster för personer i Sverige [Earnings for persons in Sweden]. Retrieved from https://www. scb.se/hitta-statistik/sverige-i-siffror/utbildning-jobb-och-pengar/ medelloner-i-sverige/. Accesed 02 Dec 2021.

SFS (2018:1197. Lag om Förenta nationernas konvention om barnets rättigheter [Law on the Convention on the Rights of Childrens], (2018). Retrieved 11-06-21 from https://www.riksdagen.se/sv/ dokumentlagar/dokument/svensk-forfattningssamling/lag-20181 197-om-forenta-nationernas-konvention_sfs-2018-1197

Skinner, C., \& Davidson, J. (2009). Recent trends in child maintenance schemes in 14 Countries. International Journal of Law, Policy, and the Family, 23(1), 25-52. https://doi.org/10.1093/lawfam/ ebn017

Socialstyrelsen/The National Board of Health and Welfare (2016) Våld: handbok om socialtjänstens och hälso- och sjukvårdens arbete med våld $i$ nära relationer [Violence: a handbook about social services' and heath cares' work with intimate partner violence]. Socialstyrelsen.

Tennent, E., \& Weatherall, A. (2019). Disclosing violence in calls for help. Gender and Language, 13(2), 270-288.

The Parental Code/Föräldrabalken, (SFS 1949:381). https://www.riksd agen.se/sv/dokument-lagar/dokument/svensk-forfattningssamling/ foraldrabalk-1949381_sfs-1949-381

Vaismoradi, M., Turunen, H., \& Bondas, T. (2013). Content analysis and thematic analysis: Implications for conducting a qualitative descriptive study. Nursing \& Health Sciences, 15(3), 398-405. https://doi.org/10.1111/nhs.12048

Williams, J. R., Ghandour, R. M., \& Kub, J. E. (2008). Female perptetrator of violence in heterosexuel realtionships: Adolescence through adulthood. Trauma, Violence \& Abuse, 9(4), 227-249. https://doi.org/10.1177/1524838008324418

Publisher's Note Springer Nature remains neutral with regard to jurisdictional claims in published maps and institutional affiliations. 